\title{
PEMANFAATAN MEDIA GOOGLE CLASSROOM PADA PEMBELAJARAN FIQIH DI MASA PANDEMI COVID 19
}

\author{
Atiqatul Musyarofah', Mega Irmawati2 ${ }^{2}$ Kholilur Rahman ${ }^{3}$ \\ 1,2,3IAI Ibrahimy Genteng Banyuwangi
}

\begin{abstract}
ABSTRAK
Seiring dengan perkembangan teknologi dan komunikasi yang pesat, di masa pandemi Covid 19 pembelajaran diselenggarakan secara online. Satu sisi, pembelajaran online mendapat apresiasi dari masyarakat. Di sisi lain timbul problem, di mana substansi pembelajaran tidak terserap dengan baik. Penelitian ini bertujuan untuk menganalisis pemanfaatan media google classroom pada masa pandemi covid-19 dalam pembelajaran fiqih di SMAN Darussholah Singojuruh Banyuwangi tahun pelajaran 2020/2021. Penelitian ini menggunakan pendekatan kualitatif deskriptif. Hasil penelitian menunjukkkan bahwa guru fiqih di SMAN Darussholah telah menyiapkan perangkat pembelajaran seperti RPP dan Silabus sebelum pembelajaran. Selain itu, guru membuat google classroom, menyiapkan materi pembelajaran dan berbagai macam alat untuk melakukan pembelajaran. Sementara, siswa membaca dan memahami materi, berdiskusi bersama tentang materi yang dibahas, dan menjawab pertanyaan/soal yang sudah diberikan oleh guru. Dalam hal evaluasi, guru melakukan tes tulis dan pembuatan video. Agar pembelajaran lebih optimal, maka guru harus profesional, tampilan media google classroom menarik, dapat diakses di mana saja. Pada saat yang sama, harus ada komunikasi yang baik antara lembaga dan guru dengan orang tua siswa. Hal ini ditujukan agar ada keberlanjutan pembelajaran fiqih di luar jam sekolah.

Kata Kunci: Media Google Classroom, Masa Pandemi, Pembelajaran Fiqih, Profesionalisme Guru.

\section{ABSTRACT}

Along with the development of technology and communication, during the Covid 19 pandemic, learning is carried out online. On the one hand, online learning has received appreciation from the community. On the other hand, a problem arises, where the learning substance is not absorbed properly. This study aims to analyze the use of google classroom media during the covid-19 pandemic in learning figh at SMAN Darussholah Singojuruh Banyuwangi for the 2020/2021 academic year. This study uses a descriptive qualitative approach. The results showed that the fiqh teacher at SMAN Darussholah had prepared learning tools such as lesson plans and syllabus before learning. In addition, the teacher created a google classroom, prepared learning materials and various tools for learning. Meanwhile, students read and understand the material, discuss together about the material discussed, and answer questions/questions that have been given by the teacher. In the evaluation, the teacher conducted a written test and made a video. So that learning is more optimal, the teacher must be professional, the appearance of the google classroom media is attractive, can be accessed anywhere. At the same time, there must be good communication between institutions and teachers and parents. This is intended so that there is continuity of fiqh learning outside school hours.

Keywords: Google Classroom Media, Pandemic Era, Fiqh Learning, Teacher Professionalism.
\end{abstract}

\section{A. Pendahuluan}

Di abad 21, dunia pendidikan, baik di lembaga formal ataupun non formal, pengarusutamaan proses pembelajaran merupakan hal yang wajib ada untuk menciptakan dan mengembangkan substansi pendidikan. ${ }^{1}$ Dalam proses pembelajaran itu sendiri juga diperlukan adanya beberapa metode serta media yang maksimal supaya

\footnotetext{
1 Sharon Kim, Mahjabeen Raza, Edward Seidman, “Improving 21st-century teaching skills: The key to effective 21st-century learners" Research in Comparative and International Education (2019). doi:10.1177/1745499919829214.
} 
proses pembelajaran dapat berjalan dengan baik. ${ }^{2}$ Keberhasilan guru dalam proses belajar mengajar erat kaitannya dengan metode, model, strategi, sumber belajar, dan media pembelajaran. Untuk mendapatkan proses pembelajaran yang menarik, maka guru perlu metode, model, strategi, sumber belajar dan media pembelajaran serta pendekatan sesuai dengan keadaan dan kebutuhan siswa. ${ }^{3}$

Dunia pendidikan saat ini tengah mendapatkan pengalaman yang sangat berharga, proses pendidikan yang biasa berpusat di sebuah gedung bernama sekolah, dengan adanya social distancing ${ }^{4}$ akhirnya proses belajar berpindah menjadi di dalam rumah-rumah siswa berbasis koneksi internet atau saluran Televisi Republik Indonesia (TVRI). Peristiwa ini adalah peristiwa yang sangat langka di tengah wabah Covid-19, proses pembelajaran siswa setidaknya akan didampingi sepenuhnya oleh orang tua yang mungkin sebagian besar juga sedang melaksanakan work from home. Pandemi Covid-19 ini sangat berdampak untuk seluruh sektor di Indonesia, baik sosial, ekonomi dan bahkan politik semua terkena dampak dari penyebaran wabah Covid-19 ini, secara sosial ini sangat terlihat perubahan di Indonesia, mulai dari diliburkan seluruh lembaga pendidikan, laranganan berkumpul di tempat umum sehingga himbauan untuk beribadah di rumah. ${ }^{5}$

Pada awal terselenggaranya pembelajaran jarak jauh oleh masyarakat dianggap sebagai jenis pendidikan alternatif atau pendidikan kelas dua yang kalah gengsinya dari pendidikan konvensional yang mengharuskan kehadiran pembelajar. Seiring dengan perkembangan teknologi dan komunikasi yang pesat, pembelajaran jarak jauh diselenggarakan secara online melalui internet. ${ }^{6}$

Pembelajaran jarak jauh secara online mendapat apresiasi yang tinggi oleh masyarakat, bahkanada yang menganggap lebih bergengsi dibandingkan pendidikan konvensional yang cenderung kurang memanfaatkan teknologi. ${ }^{7}$ Pada masa pandemi covid-19 ini kegiatan proses pembelajaran dilakukan dengan cara daring (online), dapat kita ketahui bahwa proses pembelajaran tersebut bukanlah hal yang mudah untuk kita lakukan di masa pandemi seperti ini, bahkan siswa kesulitan dalam memahami materi

2Desi Mandasari, Dkk, “Pengembangan Media PembelajaranMenggunakan Multimedia Interaktif Lectora Inspire”, Journal Pendidikan Islam, Vol. 13, No. 1 (Februari 2020): 37.

3 Zaini Tamin AR, dkk., Politik pendidikan: konsep dan praktik kebijakan pendidikan di Indonesia (Sidoarjo: $\begin{array}{llll}\text { Dwiputra Pustaka } & \text { Jaya, }\end{array}$ http://digilib.uinsby.ac.id/23919/13/Zaini\%20Tamin\%20AR\%20dkk_Politik\%20Pendidikan.pdf.

4 P. Caley, D.J.Philp, \& K. Mccracken, "Quantifying Social Distancing Arising from Pandemic Influenza”, Journal of The Royal Society Interface, Vol. 5 (2008): 631-639.

5 Ahmad Faizin, Dkk, Membaca Korona: Esai-Esai TentangManusia, Wabah, Dan Dunia (Gresik: Caramedia Communication, 2020) $<50$.

${ }_{6}^{6}$ Munir, Pembelajaran Jarak Jauh Berbasis Teknologi Informasi Dan Komunikasi (Bandung: Alfabeta,2009), 8.

7 lbid., 8-9. 
yang diberikan oleh guru sehingga kegiatan belajar mengajar tidak akan berjalan dengan baik atau kurang efektif. ${ }^{8}$ Selain itu, sebagai pendidik harus mempunyai pemikiran atau ide untuk menemukan cara yang lebih cocok yang bisa diterapkan kepada siswa dengan memanfaatkan media-media yang ada, agar materi yang di sampaikan tidak monoton dan dapatditerimadenganbaik oleh pesertadidik.Dengan adanya era teknologi yang semakin canggih dan berkembang, pendidik maupun peserta didik dituntut untuk lebih memahami, menggunakan dan memanfaatkan teknologi atau media yang ada. Dalam hal ini media internet merupakan media penting bagi siswa sebagai alat atau saran untuk mengakses dan menghubungkan berbagai informasi. ${ }^{9}$

Sebagai media baru, internet memiliki banyak kelebihan: Pertama, mendukung koneksi jaringan untuk world wide web. Kedua, menghubungkan situs resmi dalam koneksi web. Ketiga, membangunkan software dengan sumber yang terbuka atau tertutup. Keempat, semua dapat mengakses dengan berbagai latar belakang budaya dan literasi karena komputer dan bahasa yang digunakan sebagai komunikasi adalah bahasa sehari-hari. Kelima, dapat dimanfaatkan dengan email, chat, instant messaging. Keenam, internet juga dapat difungsikan sebagai blog dan situs jejaring sosial. Ketujuh, internet juga banyak dimanfaatkan sebagai hiburan seperti games, komunitas. Kedelapan, memaksimalkan internet sebagaicarakomunikasi yang difasilitasi secara digital dan mudah digunakan dalam kehidupan sehari-hari. ${ }^{10}$

Medium internet yang secara konseptual dikenal pada tahun 1970, yang harusnya secara fisik juga dikembangkan dari software bernama ARPANET yang dikembangkan pihak militer Amerika Serikat6 dalam kenyataannya juga memilili banyak batasan. Dalam kamus Merriam-Webster Online Dictionary bahwa komputer merupakan electronic communications network that connects computer networks and organizational computer facilities around the world. Menurut Your Dictionary, secara leksikal disebutkan bahwa internet refers to a collection of networks connected by routers. Definisi lainnya yaitu the global network of public computers running Internet Protocol. Dengan defenisi leksikal tersebut, substansi internet adalah menyangkut komunikasi antarmanusia di seluruh dunia melalui jaringan komunikasi elektronik yang dimungkinkan karena adanya koneksitas jaringan komputer. Dengan kata lain, internet berarti jutaan komputer di seluruh dunia yang saling bersambung. Oleh karena itu, jika

8 Firman \& Sari, "Pembelajaran Online di Tengah Pandemi Covid-19", Indonesian Journal Of Educational Science (IJES), Volume 02 No 02 (2020).

9 Lihat, Lelia Green, The internet: An Introduction To The New Media (Western Australia: Edith Cowan University., 2010).

${ }^{10}$ lbid.

El Banat Vol. 11 No. 2 (2021) 
sebuah komputer sudah tersambung dengan internet, komputer tersebut sudah terkoneksi dengan komputer-komputer lainnya melalui jaringan kabel telepon, kabel, dan satelit. Web, e-mail, chat, dan news groups merupakan beberapa hal yang dapat dilakukan pada internet. ${ }^{11}$

Dalam bidang pendidikan, internet beberapa metode pembelajaran sudah mengutamakan dengan pembelajaran online atau e-learning. Penggunaan media baru merupakan pemanfaatan yang adaptif karena mampu mengirimkan serangkaian solusi dalam metode belajar mengajar. Dengan demikian penelitian ini fokus untuk menganalisa penggunaan dan pemanfaatan salah satu media baru dalam metode belajar mengajar, yakni pemanfaatan media google classroom. ${ }^{12}$

Google Classroom adalah layanan berbasis internet yang disediakan oleh google sebuah aplikasi e-learning (pembelajaran dalam jaringan). Aplikasi ini di desain untuk membantu pendidik membuat dan membagi tugas kepada peserta didik secara paperless. Pengguna service ini harus mempunyai akun google. Selain itu Google Classroom hanya bisa digunakan oleh sekolah yang mempunyai Google Apps For. ${ }^{13}$ Salah satu pemanfaatan teknologi pada masa pandemi covid-19 ini adalah media google classroom untuk mengaksesnya, tidak memungkiri karena banyak peserta didik sekarang yang memiliki smart phone, sehingga dapat memudahkan pendidik dan peserta didik dalam melakukan proses pembelajaran. Hal ini merupakan salah satu tugas dan tanggung jawab bagi seorang pendidik dalam menggunakan dan memanfaatkan teknologi untuk diterapkan pada proses pembelajaran, bukan hanya pembelajaran umum namun juga dalam pembelajaran Fiqih. ${ }^{14}$

Pendekatan yang digunakan dalam penelitian ini adalah pendekatan kualitatif yaitu suatu prosedur penelitian yang menghasilkan data deskriptif berupa ucapan atau tulisan dan perilaku yang dapat diamati dari orang (subyek) itusendiri. Dengan pendekatan kualitatif ini, peneliti akan membuat deskripsi tentang gambaran objek yang diteliti secara sistematis, baik itu mengenai fakta-fakta, sifat-sifat serta berbagai hal yang terkait dengan tema penelitian. Pendekatan kualitatif ini digunakan karena data yang dibutuhkan berupa sebaran-sebaran informasi yang tidak perlu dikuantifikasikan. Di mana dalam penelitian ini akan menghimpun informasi terkait

${ }^{11}$ Muhammad Rustam, “Internet dan Penggunaannya (Survei di Kalangan Masyarakat Kabupaten Takalar Provinsi Sulawesi Selatan”, Jurnal Studi Komunikasi dan Media, Vol. 21 No. 1 (Januari - Juni 2017): 13 - 24.

12 Sabran Sabran, Dkk, "Keefektifan Media Google Classroom Sebagai Media Pembelajaran", Diseminasi hasil penelitian melalui optimalisasi sinta dan hak kekayaan intelektual (Februari 2019): 122

${ }^{13}$ Lukman Hakim, Perencanaan Pembelajaran (Bandung: Wacana, 2009), 2.

14 Hakim Barir, "Efektifitas Penggunaan E-Learning Moodle, Google Classroom Dan Edmodo", Jurnal IStatement. Volume 2 Nomor 1 (2016). 
dengan pemanfaatan media google classroom pada masa pandemi covid-19 dalam pembelajaran Fiqih. ${ }^{15}$ Sedangkan untuk jenis penelitian kualitatif yang digunakan dalam peneliti ini, penulis menggunakan penelitian kualitatif deskriptif dengan menerapkan suatu media google classroom untuk mengatur kondisi kelas online pada saat proses belajar-mengajar sebagai uji coba untuk mengetahui keefektifan menggunakan media yang telah diterapkan dalam pembelajaran Fiqih.

Fiqih merupakan satu rumpun dengan mata pelajaran Pendidikan Agama Islam yang wajib dipelajari oleh siswa-siswi SMA. Fiqih adalah pelajaran yang berisi mengenai hukum-hukum atau kaidah-kaidah syariat Islam. Salah satu media yang digunakan guru Fiqih di SMAN Darussholah Singojuruh adalah dengan media pembelajaran yang bervariasi dan melibatkan keaktifan siswa secara penuh dalam pembelajaran, salah satunya yaitu dengan menggunakan media google classroom. Media google classroom merupakan suatu alat atau sarana untuk melaksanakan pembelajaran online (dalam jaringan). Media ini sangat cocok digunakan untuk pendidik maupun peserta didik dalam melaksanakan proses belajar-mengajar melalui daring (dalam jaringan), karena dengan adanya media tersebut dapat mempermudah guru dalam menyampaikan materi.

\section{B. Google Classroom sebagai Alternatif Media Pembelajaran Fiqih di Tengah Pandemi}

Sebagian besar penggunaan istilah pandemic merujuk pada penyakit yang meluas secara geografis, misalnya wabah abad ke-14 (kematian hitam), kolera, influenza, dan virus human immunodecficiency virus (HIV)/ AIDS. Dalam sebuah ulasan baru-baru ini tentang sejarah influenza pandemi secarageografis dikategorikan sebagai transregional ( 2 wilayah/ negara yang berbatasan di dunia), antar regional (2 wilayah / negara yang tidak berbatasan atau bertetangga), dan global Tubenberger dan Morens. ${ }^{16}$

Di tengah pandemi Covid 19, Google Classroom adalah layanan alternatif berbasis internet yang disediakan oleh google sebagai sebuah aplikasi e-learning (pembelajaran dalam jaringan). Aplikasi ini didesain untuk membantu pendidik membuat dan membagikan tugas kepada peserta didik secara paperless. Pengguna aplikasi ini harus memiliki akun Google terlebih dahulu agar dapat mengakses aplikasi Google Classroom. ${ }^{17}$

\footnotetext{
15 Sugiyono, Metode Penelitian Kuantitatif, Kualitatif, Dan R\&D (Bandung: Alfabeta, 2019), 243.

${ }^{16}$ R. T. Handayani, dkk., "Pandemi Covid-19, Respon Imun Tubuh, dan Herd Immunity", Jurnal Ilmiyah Permas: Jurnall Imiyah Stikes Kendal Vol.10 No.3 (2020): 373-380.

${ }^{17}$ Hakim, “EfektifitasPenggunaan E-Learning Moodle, Google Classroom Dan Edmodo", Jurnal I-Statement, Volume 2 Nomor 1 (2016).
} 
Google Classroom pada media pembelajaran adalah pelaksanaan pembelajaran yang seluruhnya dilaksanakan secara online melalui sistem e-learning. Peserta didik dan pengajar sepenuhnya terpisah dan tidak diperlukan adanya tatap muka. Media pembelajaran ini disebut juga dengan web based learning dan distance learning. Seluruh bahan ajar, diskusi, penugasan, latihan, ujian, dan pembelajaran lainnya sepenuhnya disampaikan melalui e-learning. ${ }^{18}$ Google Classroom dapat diakses oleh siswa di manapun dan kapanpun tanpa batasan ruang dan waktu selama mereka masih terhubung dengan jaringan internet. Siswa dapat mengakses materi dan menggunakannya sebagai bahan untuk belajar diera pandemi. ${ }^{19}$

Dengan kata lain pengertian Google Classroom ialah suatu aplikasi yang dikhususkan suatu media pembelajaran secara online atau kelas online, sehingga dapat digunakan seorang pengajar untuk membuat, membagi, dan mengelompokkan setiap tugas tanpa menggunakan sebuah kertas. Menggunakan Google Classroom akan membuat pembelajaran menjadi lebih efektif, seorang pengajar dan peserta didik akan mudah untuk setiap saat bertatap muka melalui kelas online. Peserta didik juga dapat berperan aktif melalui kelas online tersebut dengan cara menyimak, mengirim tugas, berdiskusi. Memberikan tanggapan materi yang telah disampaikan dan diberikan oleh seorang pengajar di dalam kelas online.

Sebelum membahas pembelajaran fiqih, terlebih dahulu penulis uraikan terkait pembelajaran itu sendiri. Pembelajaran berasal dari kata "instruction" yang dalam bahasa Yunani disebut “instructus" yang artinya menyampaikan, atau ide yang telah diolah menjadi arti dalam pembelajaran. Proses belajar dikonsep guna memberikan pengalaman belajar yang mencakup proses mental dan fisik dengan melalui interaksi seorang siswa, siswa dengan guru, lingkungan serta sumber belajar lainnya guna tercapainya KD (Kompetensi Dasar). ${ }^{20}$

Menurut Karim kata fiqih berasal dari kata faqiha-yafqahu-fiqhan yang berarti “mengerti atau paham". Jadi perkataan fiqih memberi pengertian kepahaman dalam hukum syari'at yang sangat dianjurkan ole Allah dan Rasul-Nya. Adapun materi Pembelajaran Fiqih, di antaranya: ${ }^{21}$

\footnotetext{
${ }^{18}$ M. Daud Batubara, Zohri Hamdani \& Mark Philip Paderan, "Google Classroom: A Learning Media In Increasing Students' Motivation", Indonesian Journal of Learning Education and Counseling, Vol. 3 No. 2 (2021). https://doi.org/10.31960/ijolec.v3i2.893.

19 Epi Tamala,Dkk, "Pemanfaatan google classroom sebagai media pembelajaran di masa pandemi MI Nurul Huda Sukaraja”, Jurnal Pendidikan Madrasa Ibtidaiah, Vol. 4 No. 1 (Januari 2021): 6.

${ }^{20}$ Bambang Warsita, Teknologi Pembelajaran: Landasan dan Aplikasinya (Jakarta: Rineka Cipta, 2008 ), 265.

${ }^{21}$ S. Karim, Ushul Fiqih Untuk Fakultas Tarbiyah Komponen MKDK (Bandung: CV. Pustaka Media, 1997), 30.
} 
1. Pengertian zakat

Zakat adalah ibadah maliyyahijtima'iyyah yang memiliki posisi sangat penting, strategis dan menentukan, baik dilihat dari ajaran Islam maupun dari sisi pembangunan kesejahteraan umat. Ditinjau dari segi bahasa memiliki banyak arti, yaitu al-barakatu yang mempunyai arti keberkahan, ath-thaharatu yang memiliki arti kesucian, al-namaa yang mempunyai arti pertumbuhan dan perkembangan, dan ash-shalahu yang memiliki arti keberesan. Sedangkan zakat ditinjau dari segi istilah terdapat banyak ulama' yang mengemukakan redaksi yang berbeda-beda, akan tetapi pada dasarnya mempunyai maksud yang sama, yaitu bahwa zakat adalah bagian dari harta dengan persyaratan tertentu, yang Allah SWT mewajibkan kepada pemiliknya untuk diserahkan kepada seseorang yang berhak menerimanya dengan persyaratan tertentu pula. ${ }^{22}$

Dari pengertian di atas sangat jelas bahwa orang yang mengeluarkan sebagian hartanya untuk zakat akan dapat menambah kesuburan hartanya dan memperoleh keberkahan dan rahmat dari Allah SWT serta mendapat kesucian diri dari hartanya, selain itu hartanya akan senantiasa tumbuh dan berkembang menjadi lebih banyak, dan harta yang dimiliki akan selalu beres dan dijauhkan dari berbagai macam kemadharatan.

Zakat merupakan rukun Islam yang ketiga dan Allah SWT mewajibkan untuk menunaikan zakat, zakat dapat membersihkan pelakunya dari dosa dan menunjukkan kebenaran imannya, adapun caranya dengan memberikan sebagian harta yang telah mencapai nishab dalam waktu satu tahun kepada orang yang menerimanya. ${ }^{23}$ Sedangkan menurut pendapat lain, zakat merupakan rukun Islam yang ketiga dari rukun Islam yang lima, yang merupakan dasar atau pondasi bagi umat Islam untuk dilaksanakan. Zakat hukumnya adalah wajib (fardhu 'ain) bagi setiap muslim apabila sudah memenuhi syarat-syarat tertentu. ${ }^{24}$

2. Syarat dan rukun zakat

Rukun zakat yaitu unsur-unsur yang harus terpenuhi sebelum mengerjakan zakat. Rukun zakat meliputi orang yang berzakat, harta yang dijakatkan, dan orang yang berhakmenerima zakat. ${ }^{25}$ Zakat mempunyai syarat wajib dan syarat sah dalam

\footnotetext{
22D. Hafhiduddin, Zakat dalam Perekonomian Modern (Jakarta: Gemalnsani, 2002), 7.

${ }^{23}$ Baca, misalnya, Yusuf Qardhawi, Fiqh al Zakah (Beirut: Mu'assasah al Risalah, 1997).

24 Junaidi Safitri, “Implementasi Konsep Zakat dalam Al- Qur'an Sebagai Upaya Mengentaskan Kemiskinan Di Indonesia”, MUKADDIMAH: Jurnal Studi Islam, Volume 2, No. 1, (Juni 2017).

${ }^{25}$ A. Syarifuddin, Garis-Garis Besar Fiqh (Jakarta: Prenada Media, 2003), 40.
} 
pelaksanaanya. Menurut kesepakatan-kesepakatan ulama, syarat wajib zakat adalah Islam, merdeka, baligh, berakal, kepemilikanhartapenuh, mencapainishab, dan mencapaihaul. Adapun syarat sah pelaksanaan zakat adalah niat yang menyertai pelaksanaan zakat dan tamlik yaitu memindahkan kepemilikan harta kepada penerimanya. ${ }^{26}$

3. Makna zakat fitrah

Zakat fitrah yaitu zakat yang diwajibkannya terkait dengan puasa pada bulan Ramadhan, disebut pula dengansedekah fitrah. Sedekah menurut syara', dipergunakan untuk zakat yang diwajibkan, zakat fitrah seolah-olah sedekah dan fitrah satu asal kejadian, sehinga wajibnya zakat fitrah untuk mensucikannya diri dan membersihkan perbuatannya. ${ }^{27}$ Dari Ibnu Umar, Rasulullah Saw bersabda“Sesungguhnya Rasulullah SAW telah mewajibkan zakat fitrah pada bulan Ramadhan satu sha' kurma atau satu sha' gandum kepada setiap orang yang merdeka, hamba sahaya laki-laki maupun perempuan dari kaum muslim". Kata wajib dalam hadits tersebut disepakati dalam istilah syara' adalah fardhu atau keharusan bagi setiap individu umat Islam. Madzhab hanafiyah menyatakan bahwa zakat fitrah itu wajib bukan fardhu, berdasarkan kaidahnya yang membedakan antara fardhu dengan wajib. Fardhu menurut hanafiyah, segala sesuatu yang ditetapkan berdasarkan dalil qath'i (jelas/tegas), sedangkan wajib adalah segala sesuatu yang ditetapkan berdasarkan dalil dhanni. Efek dari perbedaan ini adalah bahwa orang yang mengingkari fardhu berakibat kufur, sedangkan orang yang mengingkari wajib berakibat tidak kufur. ${ }^{28}$

Dari Ibnu Umar, Rasulullah SAW bersabda“Sesungguhnya Rasulullah Saw telahmewajibkan zakat fitrah pada bulan Ramadhan satu sha' kurmaatausatu sha' gandum. Dari Abu Said al-Khudri iaberkata "kami mengeluarkan zakat fitrah, pada waktu Rasulullah Saw ada bersama kita, satu sha' makanan atau satu sha' kurma atau satu sha' gandum, atausatu sha' kurmabasahatausatu sha' gandumbasah". Dari Abu Hanifah dan sahabatnya berpendapat bahwa dianggap cukup zakat fitrah dengan setengah sha' gandum. Pendapat ini dipegang oleh mazhab Zain bin Ali dan Imam Yahya, sebagaimana dikemukakan oleh Syaukani. Hadith yang kita ketahui

\footnotetext{
${ }^{26}$ Fakhruddin, “Membumikan Zakat: Dari Taabbudi Menuju Taaqquli." JURISDICTIE, vol. 1 no. 2 (April 2010). https://doi. org/10.18860/j.v0i0.1730.

${ }^{27}$ Konstantinos Retsikas "Reconceptualising Zakat in Indonesia", Indonesia and the Malay World, Vol. 42, No. 124 (2 September 2014): 337-57. https://doi. org/10.1080/13639811.2014.951519.

28 Baca, Agus Thayib Afifi dan Ika Shabira, Kekuatan Zakat: Hidup Berkah Rezeki Berlimpah (Yogyakarta: Pustaka Albana, 2010).
} 
tentang zakat fitrah, menetapkan makanan tertentu untuk zakat fitrah, yaitu kurma kering, sya'ir, kurma basah dan susu kering yang tidak dibuang buihnya. Sebagian riwayat menetapkan tentang gandum, dan sebagian lagi biji-bijian. ${ }^{29}$

\title{
C. Implementasi Media Google Classroom pada Pembelajaran Fiqih
}

Pada penelitian ini, peneliti akan membahas tentang pemanfaatan media google classroom pada masa pandemi covid-19 dalam pembelajaran fiqih siswa kelas $X$ di SMAN Darussholah, di mana hal ini dilakukan agar pendidik dan peserta didik dapat melakukan kegiatan pembelajaran dengan semestinya meski dalam keadaan atau situasi pandemi covid-19 yang masih menyebar di berbagai penjuru dunia.

Berdasarkan hasil wawancara peneliti dengan Bapak Sudiwinoto, selaku kepala SMA Negeri Darussholah Singojuruh pada tanggal 21 April 2021, Beliau memaparkan bahwa:

\begin{abstract}
"Selama masa pandemi covid-19 ini Smanda menggunakan media google classroom untuk memudahkan pendidik maupun peserta didik dalam melaksanakan kegiatan pembelajaran daring/ online. Karena media ini sesuai untuk dilakukan pada situasi pandemi covid seperti ini. Dapat kita ketahui bahwa pada situasi seperti ini sangat sulit untuk melakukan proses pembelajaran online yang kita lakukan saat ini, tetapi saya selalu mengingatkan kepada guru-guru untuk selalu memberikan yang terbaik untuk anak-anak agar proses pembelajaran online berjalan dengan baik dan efektif "..$^{30}$
\end{abstract}

Adapun langkah-langkah dalam membuat media google classroomya itu sebagai berikut: Pertama, Membuat Kelas Baru: 1) Buka peramban (direkomendasikan Google Chrome), ketik URL http://classroom.google.com, ketik username gmail), kliktombol "berikutnya”, ketik sandi gmail dan kliktombol “masuk”; 2) Kliktombol “lanjutkan”; 3) Setelah masuk ke Google Classroom, selanjutnya akan membuat kelas baru. Klik ikon + dan klik "Buat Kelas"; 4) Centangpersetujuan dan kliktombol “lanjutkan”; 5) Isi baris pertama dengan nama kelas (Kelas IPA 1), baris kedua dengan nama mapel (Fiqih materi zakat), dan baris ketiga boleh dikosongkan. Selanjutnya klik "buat”.

Kedua, Mengundang Siswa. Klik menu "Siswa". Perhatikan kode kelas dan tombol "undang siswa". Mengundang siswa dengan cara: 1) Dengan memberikan kode kelas, dan undang via email siswa; 2) Kliktombol "undang siswa", setelahit umuncul daftar email yang sesuai dengan nama tersebut. Klik salah satu; 3) Email tersebut menempati posisinya, berikutnya klik "undang"; 4) Email sudah menempati posisi undangan. Ketiga, Membuat Deskripsi Kelas. Klik menu “tentang”, kemudian tulislah

\footnotetext{
29 Ibid.

${ }^{30}$ Wawancara Pribadi dengan Bapak Sudiwinoto, selaku kepala SMA Negeri Darussholah Singojuruh, 21 April 2021.
} 
deskripsi Kelas, selanjutnya tulislah Ruang, laluklik "simpan". Keempat, Bergabung Dengan Kelas: 1) Klik “Kelas Menu Utama”, selanjutnyaklik “Kelas”; 2) Klik ikon +, dan klik “Gabung Dengan Kelas"; 3) Ketikkodekelas, dan klik “Gabung”; 4) Sudah tergabung di kelas.

Seperti hasil wawancara dengan guru mata pelajaran Fiqih yaitu Bapak Hazizi pada tanggal 16 april 2021, Beliau memaparkan bahwa:

"Yang saya lakukan sebelum proses belajar mengajar adalah menyiapkan perangkat pembelajaran, mulai dari silabus, RPP. Ya, karena silabus bagian dari perangkat pembelajaran. Ya, karena RPP merupakan pedoman saya, acuan saya dalam melakukan kegiatan belajar mengajar, agar pelaksanaan pembelajaran dapat terlaksana dengan baik, dan berjalan dengan aktif dan efektif, serta materi yang disampaikan sesuai dengan kebutuhan peserta didik. Selain itu, hal yang harus saya persiapkan sebelum melaksanakan pembelajaran online ini, saya juga harusmembuat google classroom terlebih dahulu untuk pelaksanaan pembelajaran online nantinya, karena media yang saya gunakan pada masa pandemic ini yaitu media google classroom. Kemudian sebelum saya melaksanakan pembelajaran, saya selalu mengintruksikan kepada anakanak melalui WA grup bahwa pembelajaran online akan segera dimulai. Saya juga menyiapkan hal yang perlu disiapkan seperti materi pembelajaran yaitu materi tentang zakat, kemudian menyiapkan berbagai macam alat seperti proyektor, laptop, dan taklupa juga kuota juga harusterpenuhi. Agar pembelajaran online berjalan dengan lancar" .31

Hasil wawancara dengan pendidik tersebut dapat dipaparkan dalam proses belajar mengajar harus mempersiapkan perangkat pembelajaran terlebih dahulu. Pendidik juga menyiapkan perangkat perangkat pembelajaran berupa silabus, di mana silabus tersebut bermanfaat sebagai pedoman pengembangan perangkat pembelajaran, mulai dari perencanaan, pengelolaan kegiatan pembelajaran dan pengembangan penilaian.

Selain itu, dalam pemilihan materi harus sesuai dengan kebutuhan peserta didik dan sesuai dengan standar kompetensi dan kompetensi dasar. Seperti hasil wawancara peneliti dengan pendidik pendidikan agama islam (fiqih), beliau mengatakan bahwa:

"Kegiatan yang saya lakukan dalam menyelenggarakan kegiatan pembelajaran daring (online) untuk membuat peserta didik aktif dalam mengikuti pembelajaran daring tersebut, yang saya lakukan yaitu dengan cara memberi motivasi kepada siswa untuk berpartisipasi aktif dalam kegiatan pembelajaran daring yang kita laksanakan, menyampaikan materi sebaik mungkin agar peserta didik mudah memahami, dan juga agar peserta didik tertarik dengan adanya pembelajaran online ini menggunakan google classroom. Mengacu pada standarkompetensi dan kompetensidasar, menentukan dan menyesuaikan jenis-jenis materi dengan standar kompetensi dan kompetensidasar, dan memilihreferensi / sumberbahan ajar yang sesuai dengan materi yang diajarkan". ${ }^{32}$

Dari hasil observasi yang diperoleh peneliti di lapangan, dapat disimpulkan bahwa pendidikan agama Islam di SMA Negeri Darussholah Singojuruh telah melakukan

${ }^{31}$ Wawancara Pribadi dengan Bapak Hazizi, selaku guru PAI SMA Negeri Darussholah Singojuruh, 16 April 2021.

32Wawancara Pribadi dengan Bapak Hazizi, selaku guru PAI SMA Negeri Darussholah Singojuruh, 17 April 2021. 
perencanaan pembelajaran sebelum melakukan kegiatan proses belajar mengajar. Pendidik telah menyiapkan perangkat pembelajaran yang berupa silabus, dan RPP. Dengan adanya perangkat pembelajaran tersebut proses belajar mengajar dapat berjalan dengan efektif dan efisien.

Berdasarkan hasil wawancara peneliti dengan Bpk Hazizi selaku pendidik pendidikan agama Islam (fiqih) di SMA Negeri Darussholah Singojuruh, beliau memaparkan bahwa:

"Teknik pelaksanaan dalam menggunakan media google classroom ini saya menayangkan video terkait materi yang akan saya sampaikan kepada anak-anak nanti yaitu tentang zakat, kemudian anak-anak membaca dan memahami materi yang telah saya sampaikan terlebih dahulu, di mana dalam materi zakat tersebut terdapat beberapa penjelasan mengenai syarat, dan hukum zakat, orang yang berhak menerima zakat, macam-macam zakat. Kemudian jika saya sudah menyiapkan tugas anak-anak bisa langsung mengerjakan tugas yang telah saya sediakan itu, tugas yang saya sediakan ini biasanya berupa materi, atau pembuatan video. Selain iu, teknik pelasanaan yang saya lakukan ketika melakukan pembelajaran online ini yaitu mengadakan sesi tanya jawab sesuai materi yang sudah saya sampaikan kepada anak-anak, di mana saya membuat materi/soal yang akan di diskusikan bersama melalui media google classroom ini"33

Berdasarkan hasil wawancara di atas dapat dipaparkan bahwa yang dilakukan pendidik ketika melaksankan kegiatan belajar mengajar menggunakan google classroom pada mata pelajaran fiqih dengan materi zakat, pada materi zakat ini terdapat definisi zakat, beberapa penjelasan mengenai hukum dan syarat zakat, macam-macam zakat, dan orang yang berhak menerima zakat. Pada pelaksanaan ini pendidik menayangkan materi berupa video yang akan disampaikan kepada peserta didik terlebih dahulu yakni tentang zakat, kemudian peserta didik dapat membaca dan memahami materi yang telah disediakan oleh peserta didik tersebut. Kemudian jika pendidik menyediakan penugasan untuk peserta didik, peserta didik bisa langsung mengerjakannya. Tugas yang disediakan oleh pendidik untuk peserta didik biasanya berupa materi dan pembuatan video.

Siapapun yang berperan aktif dalam melakukan kegiatan pembelajaran online ini, hal itu merupakan awal sebuah dari penilaian/ evaluasi oleh pendidik terhadap peserta didik.

"Selama pandemi ini, saya menggunakan media google classroom untuk melakukan kegiatan pembelajaran, dengan bertujuan untuk memudahkan pendidik dalam menyampaikan materi dan memudahkanpeserta didik dalam menerima materi yang telah saya ajarkan dan saya sampaikan". ${ }^{34}$

Wawancara Pribadi dengan Bapak Hazizi, selaku guru PAI SMA Negeri Darussholah Singojuruh, 26 April $2021^{33}$

${ }^{34}$ Wawancara Pribadi dengan Bapak Hazizi, selaku guru PAI SMA Negeri Darussholah Singojuruh, 26 April 2021. 
Selain dari Kepala Sekolah dan Pendidik, peneliti juga menambahkan data dengan mewawancarai peserta didik. Berdasarkan hasil wawancara dengan Uyun Nabila pada tanggal 16 April 2021, selaku peserta didik juga mengatakan:

"Selama pandemic ini Pak Azizi mengajarnya menggunakan aplikasi google classroom mbak, cara penyampaian dan penjelasannya pak Azizi mudah di pahami. Ketika pak azizi member materi berupa video zakat ini, kita disuruh membaca dan memahamimateri yang sudah dishare terlebih dahulu sama pak azizi, terus kalau ada tugas kita suruh mengerjakan mbak. Pada materi ini kita diskusi tentang bagaimana melaksanakan zakat, ada juga macam-macam zakat, hukum dan syarat zakat, dan siapa saja orang yang bisa menerima zakat itu". ${ }^{35}$

Peneliti juga melakukan wawancara dengan peserta didik yang lain. Berdasarkan hasil wawancara dengan Wilda Fatimatul Zahra pada tanggal 22 April 2021, ia mengatakan:

"Pada masa pandemi ini Pak Azizi menggunakanaplikasigoogle classroom untuk melakukan pembelajaran online ini mbak. Pak Azizi kalau ngajar enak mbak, orangnyahumoris, jadi kita tidak bosan. Kita bisa membaca dan memahami terlebih dahulu tentang materi yang sudah disediakan oleh pak azizi melalui google classroom ini mbak, kemudian kita mengerjakan tugas yang sudah diberikan oleh Pak Azizi melalui media inimbk dan biasanya tugas itu berupa membuat video, diskusi materi”. ${ }^{36}$

Berdasarkan hasil wawancara dengan peserta didik di atas, dapat dipaparkan bahwa pendidik dalam proses belajar mengajar online ia menggunakan media google classroom untuk mengaksesnya pada mata pelajaran fiqih dengan materi zakat. Di mana pada materi ini guru dan siswa berdiskusi melalui media google classroom mengenai penjelasan zakat, hukum dan syarat zakat, macam-macam zakat, dan orang yang berhak menerima zakat tersebut. Dengan adanya media google classroom ini, dapat memudahkan pendidik dan peserta didik untuk melaksanakan pembelajaran online tersebut, peserta didik juga dapat mudah memahami materi apa yang disampaikan oleh pendidik. Pada saat yang sama, dengan adanya beberapa variasi dalam fiturnya, menambah motivasi siswa. ${ }^{37}$ Begitupun sebaliknya, pendidik juga lebih mudah dalam menyampaikan materi yang akan disampaikan kepada peserta didik.

\section{Kesimpulan}

Sesuai hasil observasi di lapangan, peneliti menyimpulkan bahwa pendidik sudah menggunakan media google classroom pada masa pandemi ini. Hal tersebut bertujuan

\footnotetext{
${ }^{35}$ Wawancara Pribadi dengan Uyun Nabila, selaku peserta didik PAI kelas X SMA Negeri Darussholah Singojuruh, 16 April 2021.

${ }^{36}$ Wawancara Pribadi dengan Wilda Fatimatul Zahra, selaku peserta didik PAI kelas X SMA Negeri Darussholah Singojuruh, 22 April 2021.

37 Batubara, Hamdani \& Paderan, “Google Classroom: A Learning Media In Increasing Students' Motivation”, Indonesian Journal of Learning Education and Counseling, Vol. 3 No. 2 (2021).
} 
untuk menjadikan pembelajaran lebih efektif, dan memudahkan pendidik dalam menyampaikan materi, serta memudahkan peserta didik dalam menerima dan memahami materi yang telah disampaikan oleh pendidik. Dalam melakukan pembelajaran online ini, pendidik juga melaksankan pembelajaran online dengan langkah-langkah yang sudah diterapkan seperti peserta didik diharuskan untuk membaca dan memahami materi yang telah disediakan oleh pendidik terlebih dahulu, yaitu materi tentang zakat. Kemudianjika pendidik memberikan atau menyediakan tugas untuk peseta didik melalui media google classroom tersebut, maka peserta didik diharuskan untuk mengerjakan tugas yang telah diberikan oleh pendidik melalui media google classroom tersebut. Selain itu, dalam pelaksanan pembelajaran online menggunakan media google classroom inipendidik juga memberikan penugasan berupa diskusi tanyajawab mengenai materi yang dibahas, membuat video, dan menjawab soal-soal yang telah diberikan oleh pendidik.

\section{E. Referensi}

Afifi, Agus Thayib, dan Shabira, Ika. Kekuatan Zakat: Hidup Berkah Rezeki Berlimpah. Yogyakarta: Pustaka Albana, 2010.

AR, Zaini Tamin, dkk., Politik pendidikan: konsep dan praktik kebijakan pendidikan di Indonesia. $\quad$ Sidoarjo: Dwiputra Pustaka Jaya, 2018. http://digilib.uinsby.ac.id/23919/13/Zaini\%20Tamin\%20AR\%20dkk_Politik\%20Pe ndidikan.pdf.

Barir, Hakim. "Efektifitas Penggunaan E-Learning Moodle, Google Classroom Dan Edmodo", Jurnal I-Statement. Volume 2 Nomor 1 (2016).

Batubara, M. Daud., Hamdani, Zohri., \& Paderan, Mark Philip. "Google Classroom: A Learning Media In Increasing Students' Motivation". Indonesian Journal of Learning Education and Counseling, Vol. 3 No. 2 (2021). https://doi.org/10.31960/ijolec.v3i2.893.

Caley, P., Philp, D. J., \& Mccracken, K. "Quantifying Social Distancing Arising from Pandemic Influenza.” Journal of The Royal Society Interface, Vol. 5 (2008): 631639.

Faizin, Ahmad., Dkk. Membaca Korona: Esai-Esai TentangManusia, Wabah, Dan Dunia. Gresik: Caramedia Communication, 2020.

Fakhruddin. "Membumikan Zakat: Dari Taabbudi Menuju Taaqquli." JURISDICTIE, vol. 1 no. 2 (April 2010). https://doi. org/10.18860/j.v0i0.1730.

Firman \& Sari. “Pembelajaran Online di Tengah Pandemi Covid-19”. Indonesian Journal Of Educational Science (IJES), Volume 02 No 02 (2020). 
Green, Lelia. The internet: An Introduction To The New Media. Western Australia: Edith Cowan University., 2010.

Hafhiduddin, D. Zakat dalam Perekonomian Modern. Jakarta: Gemalnsani, 2002.

Hakim, Lukman. Perencanaan Pembelajaran. Bandung: Wacana, 2009.

Handayani, R. T., dkk. "Pandemi Covid-19, Respon Imun Tubuh, dan Herd Immunity", Jurnal Ilmiyah Permas:Jurnall Imiyah Stikes Kendal Vol.10 No.3 (2020): 373 380 .

Karim, . Ushul Fiqih Untuk Fakultas Tarbiyah Komponen MKDK. Bandung: CV. Pustaka Media, 1997.

Kim, Sharon., Raza, Mahjabeen., Seidman, Edward. "Improving 21st-century teaching skills: The key to effective 21st-century learners". Research in Comparative and International Education (2019). doi:10.1177/1745499919829214.

Mandasari, Desi., Dkk, "Pengembangan Media PembelajaranMenggunakan Multimedia Interaktif Lectora Inspire”, Journal Pendidikan Islam, Vol. 13, No. 1 (Februari 2020): 37.

Munir. Pembelajaran Jarak Jauh Berbasis Teknologi Informasi Dan Komunikasi. Bandung: Alfabeta,2009.

Qardhawi, Yusuf. Fiqh al Zakah. Beirut: Mu’assasah al Risalah, 1997.

Retsikas, Konstantinos ."Reconceptualising Zakat in Indonesia", Indonesia and the Malay World, Vol. 42, No. 124 (2 September 2014): 337-57. https://doi. org/10.1080/13639811.2014.951519.

Rustam, Muhammad. "Internet dan Penggunaannya (Survei di Kalangan Masyarakat Kabupaten Takalar Provinsi Sulawesi Selatan”, Jurnal Studi Komunikasi dan Media, Vol. 21 No. 1 (Januari - Juni 2017): 13 - 24.

Sabran., Dkk. "Keefektifan Media Google Classroom Sebagai Media Pembelajaran", Diseminasi hasil penelitian melalui optimalisasi sinta dan hak kekayaan intelektual (Februari 2019): 122.

Safitri, Junaidi. “Implementasi Konsep Zakat dalam Al- Qur'an Sebagai Upaya Mengentaskan Kemiskinan Di Indonesia”. MUKADDIMAH: Jurnal Studi Islam, Volume 2, No. 1 (Juni 2017).

Sugiyono. Metode Penelitian Kuantitatif, Kualitatif, Dan R\&D. Bandung: Alfabeta, 2019.

Syarifuddin, A. Garis-Garis Besar Fiqh. Jakarta: Prenada Media, 2003.

Tamala, Epi., Dkk. "Pemanfaatan google classroom sebagai media pembelajaran di masa pandemi MI Nurul Huda Sukaraja", Jurnal Pendidikan Madrasa Ibtidaiah, Vol. 4 No. 1 (Januari 2021).

Warsita, Bambang. Teknologi Pembelajaran: Landasan dan Aplikasinya. Jakarta: Rineka Cipta, 2008. 
Atiqatul Musyarofah, dkk.

\section{Hasil Wawancara}

Hazizi, Wawancara, Bnyuwangi, 16 April 2021

Sudiwinoto, Wawancara, Bnyuwangi, 17 April 2021

Uun Nabila, Wawancara, Bnyuwangi, 26 April 2021

Wilda Fatimatul Zahra, Wawancara, Bnyuwangi, 22 April 2021 